\title{
Genetic transmission of Alzheimer's disease among families in a Dutch population based study
}

\author{
Cornelia M van Duijn, Lindsay A Farrer, L Adrienne Cupples, Albert Hofman
}

\section{Department of Epidemiology and Biostatistics, Erasmus University Medical School, Rotterdam, The Netherlands. $C M$ van Duijn A Hofman}

Boston University School of Medicine, Department of Neurology, 80 East Concord Street, Boston, MA 02118 USA.

L A Farrer

Department of Epidemiology and Biostatistics, School of Public Health, Boston University, Boston, Massachusetts, USA. L A Farrer L A Cupples

Department of Neurology, Harvard Medical School, Boston,

Massachusetts, USA. L A Farrer

Correspondence to Dr Farrer.

Received 26 October 1992 Revised version accepted 4 February 1993.

\begin{abstract}
We evaluated age at onset and transmission patterns of Alzheimer's disease (AD) in families of 198 patients who had onset of symptoms before the age of 65 years and were diagnosed before the age of 70 years. Patients were ascertained in a population based study in The Netherlands. The results suggest that the risk of $A D$ by the age of 90 in first degree relatives is $39 \%(95 \%$ confidence interval 27 to $51)$. By the age of 90 , this risk is $2.8(95 \%$ confidence interval 1.5-5.2) times greater than the corresponding risk of $14 \%$ among relatives of age and sex matched control subjects. Segregation analysis indicated that patterns of familial clustering are best explained by transmission of a major autosomal dominant gene with reduced penetrance and a multifactorial component. However, the single major locus model could be rejected in favour of the mixed model only when a cohort effect for heritability was allowed for. The frequency of the $A D$ susceptibility allele was estimated to be $0.48 \%$ in the single major locus model and $0.31 \%$ in the mixed model. Although our study confirms that a dominant major gene is implicated in early onset $A D$, the results suggest that other genetic or perhaps non-genetic factors may account for the disease in a considerable number of patients.

( $($ Med Genet 1993;30:640-6)
\end{abstract}

The tendency for Alzheimer's disease (AD) to cluster in families is well recognised. ${ }^{1}$ There is evidence for autosomal dominant inheritance in a considerable number of families with multiple affected members. ${ }^{2}$ Identification of defects in the gene coding for $\beta$ amyloid processing protein in patients from some families ${ }^{3-7}$ and evidence for linkage of early onset familial AD (FAD) to chromosome $14^{8-11}$ and late onset FAD to chromosome $19^{12}$ has fuelled speculation that the familial component in $\mathrm{AD}$ is accounted for by genetic transmission. However, observations of sporadic occurrence in approximately $50 \%$ of $\mathrm{AD}$ cases, ${ }^{13-16}$ similar concordance rates in the range of $50 \%$ for $\mathrm{AD}$ among $M Z$ and $D Z$ twin pairs, ${ }^{17-19}$ and a significantly higher number of patients with a posit- ive family history of $\mathrm{AD}$ in first degree relatives among $\mathrm{MZ}$ twin pairs concordant for $\mathrm{AD}$ than in discordant $M Z$ twins pairs ${ }^{20}$ suggest that the genetic susceptibility to $\mathrm{AD}$ in many people is either lacking or insufficient to cause symptoms. Differences in methodology may underlie this wide range in risk estimates. On the other hand, it is also conceivable that these discrepancies may be because of heterogeneity. ${ }^{21}$

Interpretation of familial risk data from survey studies ${ }^{14223}$ is difficult because of censoring of unaffected relatives. In other words, even elderly relatives who are unaffected at the time of the study may yet develop or could have developed the illness at a later age. Survival analysis studies ${ }^{24-27}$ have quantified life time risk more accurately, but these methods are unable to distinguish an inherited risk factor from environmental transmission or discriminate between unifactorial and multifactorial disease models.

It has been suggested that genetics may differ between early and late onset $A D$ and that the early onset form (onset before 65 years) may be explained as an autosomal dominant trait. ${ }^{21} 28$ Previous studies have been too small to yield precise risk estimates for early onset $\mathrm{AD}$. Another problem in the interpretation of earlier investigations is that case series have been hospital based. Since referral of the patients to a particular hospital may have been related to the history of dementia in the family, selection bias may have occurred when studying the extent of genetic involvement in the disease. As to the pattern of genetic transmission, to date only one formal segregation analysis involving rigorously diagnosed cases has been published.29 This study suggested that one or more major dominant genes may be implicated in AD but that other genetic or non-genetic mechanisms appear to play a substantial role. However, these findings remain to be confirmed. ${ }^{21} 29$

We have studied the pedigrees of 198 patients with an onset of $\mathrm{AD}$ before the age of 65 and of 198 age and sex matched controls. Patients and controls were derived from a Dutch population based study of risk factors for early onset $\mathrm{AD}$. The purpose of this study was to clarify the genetic transmission of early onset $\mathrm{AD}$ using data of a population based unbiased sample of $\mathrm{AD}$ patients. The study aimed to estimate the 
risk of $\mathrm{AD}$ for first degree relatives of patients with early onset $\mathrm{AD}$ and to delineate the mode of inheritance of early onset $\mathrm{AD}$.

\section{Methods \\ SUBJECTS}

For this study, patients in whom the age at onset was before the age of 65 years and in whom the diagnosis of $\mathrm{AD}$ was made before the age of 70 years in the period of January 1980 to July 1987 were eligible. Details of the study design have been published earlier. ${ }^{30}$ The study was population based and aimed at complete ascertainment of all cases with early onset AD living in two areas of The Netherlands (the four northern provinces and the region of the city of Rotterdam). All nursing homes, psychiatric institutions, social-geriatric services, neurologists, and facilities for computed tomography in the specified areas were asked for patients with dementia in order to obtain full ascertainment of early onset cases. The patients were then seen by two physicians who independently confirmed the diagnosis of probable $\mathrm{AD}$ using a standard protocol similar to NINCDS/ADRDA criteria. ${ }^{31}$ Only patients for whom there was consensus on the clinical diagnosis of probable $\mathrm{AD}$ were included in the study. Dementias other than AD (for example, multi-infarct dementia, Parkinson's disease, and dementia secondary to alcoholism, depression, metabolic disorders, and other conditions) were excluded on the basis of the clinical history, neurological examination, and neuropsychological and laboratory tests.

The inclusion criteria for patients were: a typically slow progressive decline of intellectual function ${ }^{31}$; a score on the Clinical Dementia Rating scale of more than $0.5^{32}$; a score on the Short Portable Mental Status Questionnaire (SPMSQ) of less than 20 (out of 30 in the Dutch version we have used) ${ }^{33}$; a score of 7 or less (out of 18) on the Hachinski scale ${ }^{34}$; no evidence of abnormalities on computed tomography other than cerebral atrophy, nor of focal dysfunction on electroencephalography. Of the 278 patients brought to our attention, 201 satisfied these criteria. The family of one patient refused cooperation and for two others no informant could be found. In $198(98 \%)$ patients, data on risk factors were obtained along with a serum sample. The age at onset was 55 years or younger in 56 patients, between 55 and 59 years in 76 patients, and between 60 and 65 in 66 patients.

For each patient a reference subject was selected and matched for age (within five years), gender, and place of residence. These controls were drawn randomly from the population register of the municipality of the patient at the time of diagnosis. All control subjects had a SPMSQ score of 20 or over. For controls, the first person asked consented in 103 cases $(52 \%)$, in $68(34 \%)$ it was the second selected person, in $23(12 \%)$ the third, and in four $(2 \%)$ the fourth.

\section{DATA COLLECTION}

We did not examine the relatives of the probands because a considerable number of first degree relatives were already dead at the time of study. However, detailed data on family history were collected by interviewing a next of kin of the patient or control. This informant was asked specifically about the occurrence of dementia in all first degree relatives. To increase the validity of the family history data, the information was always verified by a sib of the patient or control. Four subjects born outside The Netherlands were excluded from the analysis because their sibs could not be contacted. Onset age of dementia was defined as the age at which memory loss or change in behaviour was first noted. For non-demented relatives, the censoring age was determined, that is, the age at time of the study or the age at death.

We questioned informants extensively on the cause and the course of the dementia in affected relatives. The diagnosis was checked in independent medical records for demented persons who had been admitted to a hospital. Because relatives may have been diagnosed before standardised diagnostic criteria were available, all relatives reported as demented were re-evaluated using data from multiple informants and information derived from medical records. Relatives with a history of neurological, psychiatric, or metabolic disorders that may also lead to dementia (for example, stroke, Parkinson's disease, epilepsy, depression, or alcoholism) were classified as unaffected. All other relatives with a type of dementia that was reported as being irreversible and progressive were classified as affected with possible AD. Medical records were available for $36(32 \%)$ of the affected relatives. Pedigrees of the families are available upon request.

\section{ESTIMATION OF LIFE TIME RISK AND AGE AT} ONSET DISTRIBUTION

Risks of dementia and the age at onset distribution for first degree relatives of the $\mathrm{AD}$ probands and control subjects were estimated using a maximum likelihood procedure. ${ }^{35}$ This method considers not only affected persons with known onset ages and unaffected persons with known censoring ages (that is, those persons typically included in a Kaplan-Meier survival analysis ${ }^{36}$ ), but also persons for whom onset age or censoring age data are missing. This method also allows for the possibilities that a proportion of relatives asymptomatic at the time of study may be susceptible and express the disease later in life and that some dead relatives may have died from causes unrelated to $\mathrm{AD}$ although they may have developed symptoms had they survived. Parameter estimates for the estimated life time risk and mean onset age were compared between $\mathrm{AD}$ relatives and control relatives and among subgroups of $\mathrm{AD}$ relatives at the oldest onset age common to both groups. Since asymptotically these maximum likelihood statistics have normal distributions, a large sample $Z$ statistic was used. ${ }^{37}$ For the purpose of these analyses, probands were stratified by age at onset of 58 years because this age was calculated using maximum likelihood as the most parsimonious cut off between families with early onset FAD 
Table 1 Variables considered in segregation analysis.

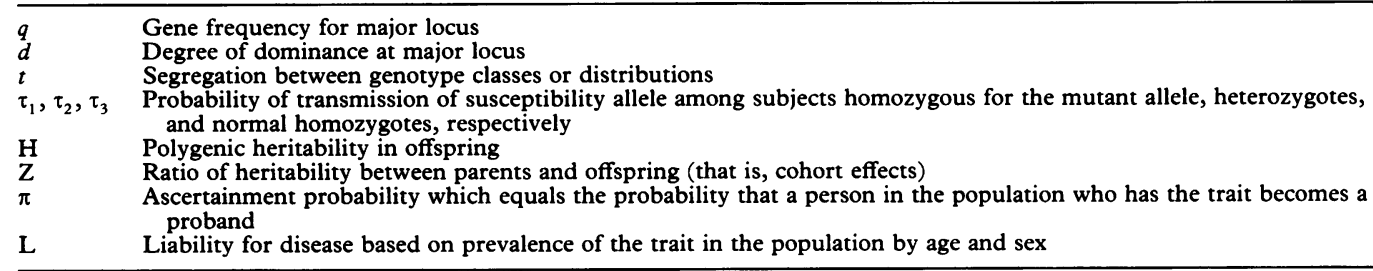

and late onset FAD. ${ }^{2}$ Life time risk of $\mathrm{AD}$ to first degree relatives and, hence, the inferred mode of transmission, differed in these two groups of families.

SEGREGATION ANALYSIS METHODS

Segregation analysis is the evaluation of models of transmission accounting for the distribution of a trait in families. This approach uses a maximum likelihood method ${ }^{38}$ which permits joint consideration of several independent parameters of the transmission model (table 1). A variety of single gene models, polygenic models, mixed models (that is, liability to $\mathrm{AD}$ determined by a major locus component, a polygenic background, and random environment), ${ }^{390}$ and sporadic models were tested using the computer program POINTER. ${ }^{41}$ These data represent a biased sample because all families were selected on the basis of at least one affected member. An ascertainment correction was applied which considered the type of ascertainment and the ascertainment probability, $\pi^{42}$ (table 1 ). Although all $\mathrm{AD}$ cases diagnosed before 70 years and living in the catchment area were identified, ascertainment approaches single selection because the likelihood for any family having more than one living affected member diagnosed before 70 years is very small (in fact, only one family had multiple probands). Hence, $\pi$ was assumed to be 0.001 . As the risk of $\mathrm{AD}$ increases rapidly with age and the average censoring age was higher in parents than in sibs, bias may occur when studying the transmission patterns of disease within a family. To adjust for the age related increased risk of $\mathrm{AD}$, parents of all probands were considered lost to follow up after the age of 81 years, which was the oldest observed onset age among sibs. Those with an onset of disease after the age of 81 were considered unaffected and lost to follow up at the age of 81 . The age and sex adjusted cumulative incidence up to the age of 81 in control subjects was used to determine liability of developing $A D$ for each subject (table 2). Data were analysed under

Table 2 Liability classes used in segregation analysis.

\begin{tabular}{|c|c|c|c|}
\hline \multirow[b]{2}{*}{ Class } & \multicolumn{2}{|c|}{ Age range (years) } & \multirow{2}{*}{$\begin{array}{l}\text { Cumulative } \\
\text { incidence }\end{array}$} \\
\hline & Men & Women & \\
\hline 1 & $0-55$ & $0-60$ & 0.004340 \\
\hline 2 & $56-62$ & $61-62$ & 0.007973 \\
\hline 3 & $63-70$ & $63-69$ & 0.015655 \\
\hline 4 & $71+$ & $70-73$ & 0.027684 \\
\hline 5 & - & 74-75 & 0.034719 \\
\hline 6 & - & $76-77$ & 0.042097 \\
\hline 7 & - & $78-79$ & 0.056791 \\
\hline 8 & - & $80+$ & 0.066011 \\
\hline
\end{tabular}

different assumptions for $\pi$ and cumulative incidence. Results of these analyses did not change any of the conclusions.

\section{Results}

SURVIVAL ANALYSIS RESULTS

Over a life span of 90 years, the risk for dementia to first degree relatives of $\mathrm{AD}$ probands is $39 \%$ (SE 6) which is significantly greater than the corresponding risk of $14 \%$ (SE 4) among relatives of controls subjects (table 3). The mean onset ages for the two groups were not significantly different. These findings suggest that although the relative proportions of early onset and late onset cases are similar among relatives of $\mathrm{AD}$ probands and relatives of controls, the risk of $\mathrm{AD}$ is higher in relatives of $\mathrm{AD}$ cases at all ages (fig 1). The relative risk for Alzheimer's disease by the age of 90 for those with a first degree affected relative is 2.8 (95\% confidence interval $1.5-$ 5.2).

Among first degree relatives of the $\mathrm{AD}$ cases, the risk of developing $\mathrm{AD}$ was higher in women than in men at all ages. By the age of 86 , women have a $15 \%$ higher risk than men of developing $\mathrm{AD}$. Moreover, the mean age of onset was significantly higher in women (79.8 years) than men ( 73.0 years). Parents of $\mathrm{AD}$ cases had 1.4 times $(0.26 / 0.18)$ the risk of sibs for developing $\mathrm{AD}$ by the age of 81 but this difference was not significant. At all ages, the risk of $\mathrm{AD}$ was higher among parents than among sibs (fig 2). Although first degree relatives of probands with an onset of disease before the age of 58 tended to have a higher risk of dementia, further stratification showed that this finding could be attributed to the $70 \%$ risk among female relatives of early onset cases. Similar risks and onset ages were found among relatives of male and female probands.

\section{SEGREGATION ANALYSIS RESULTS}

Formal testing of 15 hypotheses regarding transmission of AD in families was carried out by segregation analysis. The maximum likelihood estimates of the parameters (described in table 1) for each model are presented in table 4 . Values in parentheses were fixed in accordance with the model being tested. The $-2 \mathrm{log}$ likelihood values for the corresponding models were compared by a likelihood ratio $\left(\chi^{2}\right)$ test in a sequential fashion. The hypothesis that susceptibility to AD is not transmitted is strongly rejected when compared to models of multifactorial $\left(\chi_{1}^{2}=237.15, \mathrm{p}<0.0001\right)$ or mendelian $\left(\chi_{3}^{2}=254.75, \mathrm{p}<0.0001\right)$ inheritance. Among models postulating a single major locus or a 
Table 3 Estimated life time risk of Alzheimer's disease (AD) and the age at onset distribution among first degree relatives among stratified groups of $A D$ probands and controls.

\begin{tabular}{|c|c|c|c|c|c|c|c|c|}
\hline \multirow{3}{*}{$\begin{array}{l}\text { Comparison } \\
\text { group }\end{array}$} & \multirow{2}{*}{\multicolumn{2}{|c|}{ No of relatives in group }} & \multirow{3}{*}{$\begin{array}{l}\text { Oldest } \\
\text { onset } \\
\text { age }(y)\end{array}$} & \multicolumn{3}{|c|}{ Risk } & \multirow{2}{*}{\multicolumn{2}{|c|}{ Onset age (y) }} \\
\hline & & & & \multirow{2}{*}{$\begin{array}{l}\text { Lifetime } \\
\operatorname{risk}(\mathrm{SE})\end{array}$} & \multirow{2}{*}{$\begin{array}{l}\text { Comparison } \\
\text { risk }(\mathrm{SE})^{*}\end{array}$} & \multirow[b]{2}{*}{$\mathbf{Z}+$} & & \\
\hline & Affected & Unaffected & & & & & Mean (SE) & $\mathbf{Z}^{+}$ \\
\hline $\begin{array}{l}\text { All } \\
\text { Controls }\end{array}$ & $\begin{array}{r}127 \\
32\end{array}$ & $\begin{array}{l}1181 \\
1187\end{array}$ & $\begin{array}{l}90 \\
90\end{array}$ & $\begin{array}{l}0.39(0.06) \\
0.14(0.04)\end{array}$ & $\begin{array}{l}0.39(0.06) \\
0.14(0.04)\end{array}$ & $3.47 \S$ & $\begin{array}{l}77.7(1.6) \\
81.4(1.8)\end{array}$ & 1.54 \\
\hline $\begin{array}{l}\text { Males } \\
\text { Females }\end{array}$ & $\begin{array}{l}48 \\
79\end{array}$ & $\begin{array}{l}620 \\
561\end{array}$ & $\begin{array}{l}86 \\
90\end{array}$ & $\begin{array}{l}0.22(0.04) \\
0.56(0.10)\end{array}$ & $\begin{array}{l}0.22(0.04) \\
0.37(0.05)\end{array}$ & $2.34+$ & $\begin{array}{l}73.0(1.9) \\
79.8(1.8)\end{array}$ & $2.60_{+}^{+}$ \\
\hline $\begin{array}{l}\text { Parents } \\
\text { Sibs }\end{array}$ & $\begin{array}{l}81 \\
46\end{array}$ & $\begin{array}{l}306 \\
875\end{array}$ & $\begin{array}{l}90 \\
81\end{array}$ & $\begin{array}{l}0.42(0.06) \\
0.18(0.05)\end{array}$ & $\begin{array}{l}0.26(0.06) \\
0.18(0.05)\end{array}$ & 1.37 & $\begin{array}{l}75.7(1.8) \\
71.4(2.6)\end{array}$ & 1.36 \\
\hline $\begin{array}{l}\text { Proband onset } \leqslant 58 \\
\text { Proband onset }>58\end{array}$ & $\begin{array}{l}68 \\
59\end{array}$ & $\begin{array}{l}566 \\
615\end{array}$ & $\begin{array}{l}90 \\
90\end{array}$ & $\begin{array}{l}0.48(0.09) \\
0.32(0.07)\end{array}$ & $\begin{array}{l}0.48(0.09) \\
0.32(0.07)\end{array}$ & 1.40 & $\begin{array}{l}78.5(2.1) \\
76.9(2.4)\end{array}$ & 0.50 \\
\hline $\begin{array}{l}\text { Males, proband onset } \leqslant 58 \\
\text { Males, proband onset }>58\end{array}$ & $\begin{array}{l}24 \\
24\end{array}$ & $\begin{array}{l}311 \\
309\end{array}$ & $\begin{array}{l}83 \\
86\end{array}$ & $\begin{array}{l}0.20(0.05) \\
0.24(0.06)\end{array}$ & $\begin{array}{l}0.20(0.05) \\
0.22(0.06)\end{array}$ & 0.26 & $\begin{array}{l}70.4(2.8) \\
75.1(2.4)\end{array}$ & 0.27 \\
\hline $\begin{array}{l}\text { Females, proband onset } \leqslant 58 \\
\text { Females, proband onset }>58\end{array}$ & $\begin{array}{l}44 \\
35\end{array}$ & $\begin{array}{l}255 \\
306\end{array}$ & $\begin{array}{l}90 \\
90\end{array}$ & $\begin{array}{l}0.70(0.12) \\
0.40(0.14)\end{array}$ & $\begin{array}{l}0.70(0.12) \\
0.40(0.14)\end{array}$ & 1.63 & $\begin{array}{l}79.8(1.9) \\
78.9(3.7)\end{array}$ & 0.22 \\
\hline $\begin{array}{l}\text { Male proband families } \\
\text { Female proband families }\end{array}$ & $\begin{array}{l}49 \\
78\end{array}$ & $\begin{array}{l}416 \\
765\end{array}$ & $\begin{array}{l}90 \\
89\end{array}$ & $\begin{array}{l}0.39(0.09) \\
0.38(0.07)\end{array}$ & $\begin{array}{l}0.37(0.08) \\
0.38(0.07)\end{array}$ & 0.09 & $\begin{array}{l}77.8(2.6) \\
77.2(2.0)\end{array}$ & 0.18 \\
\hline
\end{tabular}

* Risk at maximum age common to both groups (that is, the smaller of the two oldest onset ages).

+ Test for difference between comparison groups.

$\ddagger \mathrm{p}<0.01 \quad \S \mathrm{p}<0.001$

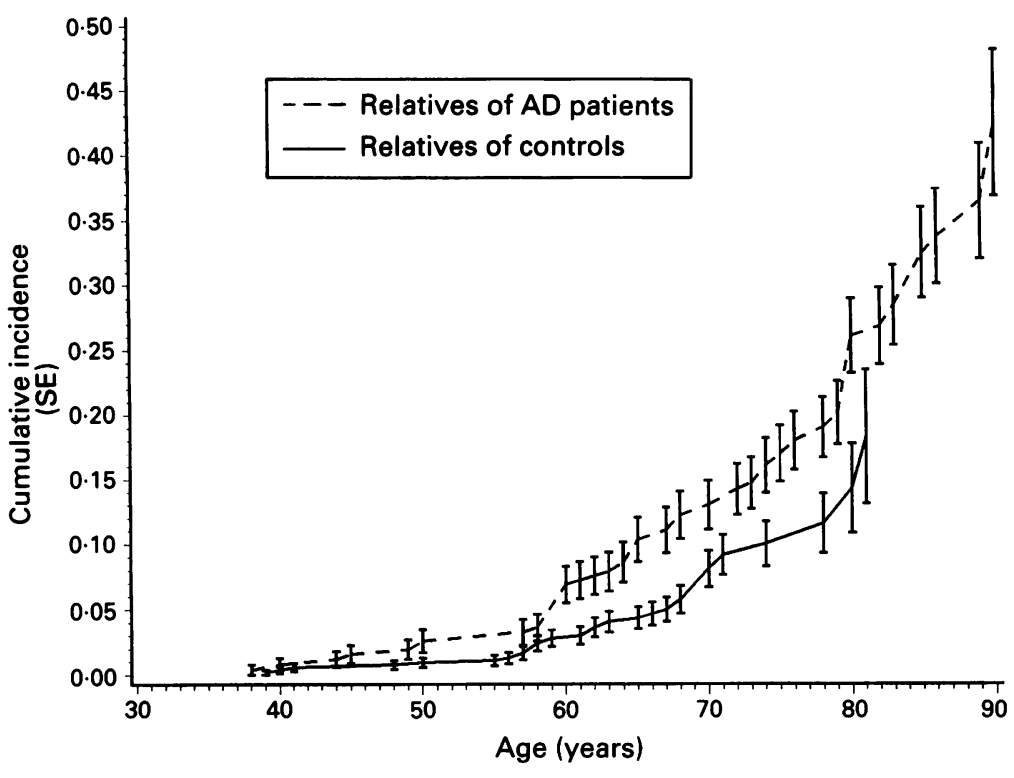

Figure 1 Estimated life time incidence of Alzheimer's disease ( $A D)$ in first degree relatives of $A D$ probands and control subjects. Vertical lines show standard errors at each age value for onset in affected relatives.

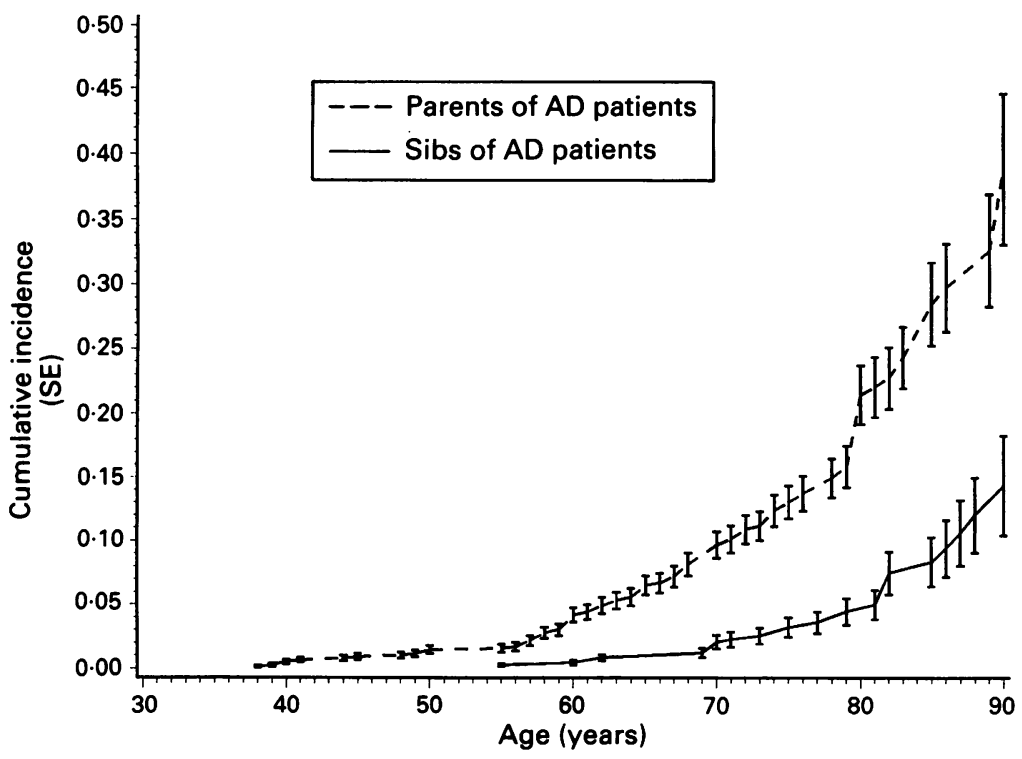

Figure 2 Estimated life time incidence of Alzheimer's disease (AD) in parents and sibs of $A D$ probands. Vertical lines show standard errors at each age value for onset in affected relatives. mixed model for $\mathrm{AD}$, recessive inheritance is very unlikely (model $4 v$ model $7: \chi_{1}^{2}=126.14$, $\mathrm{p}<0.0001$; model $9 v$ model 12: $\chi_{1}^{2}=17.62$, $\mathrm{p}<0.0001$ ). Hypotheses suggesting that susceptibility to $\mathrm{AD}$ is determined by multifactorial inheritance only are also rejected in favour of the mixed models (model $2 v$ model 12: $\chi_{3}^{2}=17.62, \mathrm{p}=0.0005$; model $3 v$ model 14: $\chi_{3}^{2}=10.98, \mathrm{p}=0.012$ ). Among the mixed models, mendelian transmission of the disease is not rejected, that is, $\tau_{1}, \tau_{2}$, and $\tau_{3}$ do not differ significantly from $1,0.5$, and 0 , respectively (model $12 v$ model 13: $\chi_{3}^{2}=1.38, \mathrm{p}=0.71$; model $14 v$ model 15: $\left.\chi_{1}^{2}=0.01, \mathrm{p}>0.9\right)$. Single major locus inheritance (model 7) can be rejected in favour of the mixed model 14 only when a cohort effect (that is, $Z$, the parent to child heritability ratio) is not constrained to one $\left(\chi_{2}^{2}=16.50, \mathrm{p}=0.0003\right)$. The best model fitted to our data (model 14) suggests that the $\mathrm{AD}$ susceptibility allele at the major locus has a frequency of $0.31 \%$ and behaves in an autosomal dominant manner. The $\mathrm{AD}$ susceptibility allele at the major locus is $61 \%$ penetrant. In this model, approximately $2 \%$ of the variance in patterns of familial aggregation of $\mathrm{AD}$ is accounted for by the major locus and $21 \%$ is accounted for by a multifactorial component. Therefore it may be inferred that $77 \%$ of the variance is unaccounted for. Assuming a single major locus (model 7), 4\% of the variance is accounted for by the major locus and $96 \%$ of the variance is unaccounted for.

\section{Discussion}

Our study indicates that the risk of $\mathrm{AD}$ by the age of 90 in first degree relatives of patients with clinically diagnosed early onset $\mathrm{AD}$ is $39 \%$, and this risk is almost three times greater than the corresponding risk among relatives of control subjects. On the basis of this comparison alone, one would conclude that susceptibility to $\mathrm{AD}$ has a strong genetic component, but it is unlikely that an autosomal dominant model can fully explain transmission of $\mathrm{AD}$ in these families because the risk is much less than $50 \%$. However, given the wide confidence interval on this estimate $(27-51 \%$ ), a risk of $50 \%$, and, hence, dominant inheritance 
Table 4 Segregation analysis of Alzheimer's disease.

\begin{tabular}{|c|c|c|c|c|c|c|c|c|c|c|}
\hline Model & Hypothesis & $d$ & $t$ & $q$ & H & Z & $\tau_{1}$ & $\tau_{2}$ & $\tau_{3}$ & $-2 \ln L+C$ \\
\hline \multicolumn{2}{|c|}{1 Sporadic } & - & - & (0) & (0) & (1.0) & - & - & - & -788.66 \\
\hline \multicolumn{11}{|c|}{ Multifactorial } \\
\hline 3 & Cohort effect & - & - & (0) & 0.49 & 2.01 & - & $\overline{-}$ & $\overline{-}$ & $\begin{array}{l}-1025.81 \\
-1048.93\end{array}$ \\
\hline $\begin{array}{l}\text { Sing } \\
4 \\
5 \\
6 \\
7 \\
8\end{array}$ & $\begin{array}{l}\text { e locus } \\
\text { Recessive } \\
\text { Codominant } \\
\text { Dominant } \\
\text { Unrestricted } d \\
\text { Unrestricted } d \text { and } \tau\end{array}$ & $\begin{array}{r}(0) \\
(0.5) \\
(1.0) \\
0.33 \\
0.42\end{array}$ & $\begin{array}{r}15.27 \\
4.08 \\
2.08 \\
6.08 \\
5.31\end{array}$ & $\begin{array}{l}0.03911 \\
0.00476 \\
0.00439 \\
0.00483 \\
0.00389\end{array}$ & $\begin{array}{l}(0) \\
(0) \\
(0) \\
(0) \\
(0)\end{array}$ & $\begin{array}{l}(1.0) \\
(1.0) \\
(1.0) \\
(1.0) \\
(1.0)\end{array}$ & $\begin{array}{l}(1.0) \\
(1.0) \\
(1.0) \\
(1.0) \\
1.0\end{array}$ & $\begin{array}{l}(0.5) \\
(0.5) \\
(0.5) \\
(0.5) \\
0.59\end{array}$ & $\begin{array}{c}(0) \\
(0) \\
(0) \\
(0) \\
0\end{array}$ & $\begin{array}{r}-917.27 \\
-1043.31 \\
-1042.35 \\
-1043.41 \\
-1044.93\end{array}$ \\
\hline \multicolumn{2}{|c|}{ Mixed mode } & (l) & 0. & 0.00 & 0.62 & (1.0) & $(1.0)$ & $(0.5)$ & (0) & -1025.81 \\
\hline 10 & $\begin{array}{l}\text { Codominant major } \\
\text { locus }\end{array}$ & $(0.5)$ & 4.0 & 0.004 & 0.04 & $(1.0$ & (1.0) & $(0.5)$ & (0) & -1043.37 \\
\hline $\begin{array}{l}11 \\
12 \\
13\end{array}$ & $\begin{array}{l}\text { Dominant major locus } \\
\text { Unrestricted } d \\
\text { Unrestricted } d \text { and } \tau\end{array}$ & $\begin{array}{l}(1.0) \\
0.37 \\
0.22\end{array}$ & $\begin{array}{r}2.06 \\
5.45 \\
10.76\end{array}$ & $\begin{array}{l}0.0040 \\
0.0046 \\
0.0032\end{array}$ & $\begin{array}{l}0.13 \\
0.04 \\
0.04\end{array}$ & $\begin{array}{l}(1.0) \\
(1.0) \\
(1.0)\end{array}$ & $\begin{array}{l}(1.0) \\
(1.0) \\
1.0\end{array}$ & $\begin{array}{c}(0.5) \\
(0.5) \\
0.63\end{array}$ & $\begin{array}{c}(0) \\
(0) \\
0\end{array}$ & $\begin{array}{l}-1042.60 \\
-1043.43 \\
-1044.81\end{array}$ \\
\hline \multicolumn{11}{|c|}{ General transmission } \\
\hline 14 & $\begin{array}{l}\text { Mendelian major locus } \\
\text { with cohort effects }\end{array}$ & 0.61 & 3.12 & 0.0031 & 0.21 & 4.67 & (1.0) & $(0.5)$ & (0) & -1059.91 \\
\hline 15 & Unrestricted model & 0.67 & 2.86 & 0.0032 & 0.21 & 4.69 & 1.0 & 0.51 & 0 & -1059.92 \\
\hline
\end{tabular}

as the sole mechanism for $\mathrm{AD}$ transmission cannot be excluded without doing a formal pedigree analysis.

Other studies ${ }^{24-2643}$ have reported life time risks that approach $50 \%$, but these values may be inflated because of estimation bias associated with a paucity of unaffected persons who survive to very late ages (sample size issue) and ascertainment biased towards cases with a positive family history. In contrast, the life time risk for $\mathrm{AD}$ of $39 \%$ is in remarkable agreement with the maximum risk estimate of $39 \%$ obtained by Farrer et al, ${ }^{27}$ despite the differences between the studies in ascertainment and age of onset of probands.

Although the risk of dementia was higher among parents than sibs at all ages, survival analysis also showed that life time risks to parents and sibs by the age of 81 were statistically indistinguishable, a finding consistent with other studies. ${ }^{2426}$ The raised risk to females is still apparent after adjusting for differential survival between men and women. Although this difference may reflect enhanced genetic expression among women, ${ }^{1924}$ the risk of $70 \%$ among female relatives of probands with onset $\leqslant 58$ years is higher than expected for autosomal dominant inheritance, suggesting the existence of excess phenocopies among women.

Other complex segregation analysis suggests that patterns of familial clustering are best explained by a mixed model, in which there is transmission of a major autosomal dominant gene and a multifactorial component. These findings are consistent with the results of the survival analysis in table 3 . As $\mathrm{Z}$ is significantly greater than one, the polygenic component seems to be stronger in the parental generation than in the offspring generation in Dutch families. This trend is in agreement with the higher risk estimates for parents than for sibs at all ages (fig 2). Biologically, the strong generational effect is difficult to interpret. It may be argued that our method for correcting the censoring bias may not have adequately accounted for the fact that the majority of the unaffected sibs are relatively young (mean $=59.0$ [SE 18.8], median $=64$ ) and, therefore, still have substantial risk of developing $\mathrm{AD}$. If the generational effect is ignored, there is no significant evidence for multifactorial inheritance and familial aggregation in this population is consistent with a single major gene model.

At present two formal segregation analyses have been published. ${ }^{2944} \mathrm{McGuffin}$ et al $^{44}$ could not reject multifactorial inheritance as the mode of transmission in a segregation analysis of two Scandinavian studies. ${ }^{2245}$ However, these studies were carried out before the availability of operational diagnostic criteria and standardised methods for reliable classification of unexamined cases. Also patients with Pick's disease confirmed at necropsy were included in these analyses. Our findings are consistent with the segregation analysis findings of Farrer et $a l,{ }^{29}$ who studied segregation of $\mathrm{AD}$ in first degree relatives of 232 cases with early or late onset $\mathrm{AD}$. Models postulating no transmission and multifactorial inheritance only were rejected in both studies. However, in the study of Farrer et al, ${ }^{29}$ who assumed a very conservative cumulative incidence $(0.0065)$, the evidence for multifactorial inheritance in the mixed models was independent of the cohort effect. A reanalysis of their data using a cumulative incidence of 0.17 , which is more compatible with the incidence of $A D$ reported in a US population based epidemiological study, ${ }^{46}$ gave estimates for $q(0.0023), h(0.21)$, and $\tau_{2}$ $(0.50)$, which are very similar to the present study (unpublished results).

There may be several caveats to the interpretation of our findings including diagnostic uncertainty (particularly among unexamined relatives) and robustness of the parameter estimates. Specifically with regard to the life time risk estimates, it has been shown that definition of onset of disease may influence the risk estimates. ${ }^{47}$ Although our definition may have led to an underestimation of the true risk, ${ }^{47}$ a shift in the assignment of onset age would have little impact on the conclusions from the segregation analysis.

The pitfalls of segregation analysis of late onset disorders are well recognised (for a detailed discussion of the methodological issues regarding segregation analysis see reference 29). We cannot exclude the possibility 
that a considerable percentage of the variance in patterns of familial aggregation of $\mathrm{AD}$ not accounted for by autosomal dominant or multifactorial inheritance may be explained by erroneous pedigree information (for example, diagnostic uncertainty or censoring). In support of our results, we used rigorous and standardised diagnostic criteria and scrutinised the data under several different assumptions of disease prevalence and ascertainment probability. Furthermore, we used multiple informants which has been shown to increase the reliability of family history data. ${ }^{48}$ Another important strength of our study is the population based design, which makes it unlikely that selection bias has occurred.

It is important to note that widely used computer programs for segregation analysis (for example, POINTER, ${ }^{41}$ PAP, ${ }^{49}$ SAGE, ${ }^{50}$ and $M E N D E L^{51}$ ) are limited to conventional genetic models for transmission of disease which allow for inheritance through a major gene with two alleles and multifactorial inheritance. More complex genetic models (for example, major gene with multiple alleles for susceptibility, oligogenic models in which the disease is determined by a small number of unlinked loci, and models involving epistasis in which expression of the major susceptibility allele is masked by another gene) are not considered. A method for segregation analysis of a two locus disease trait has been developed ${ }^{52}$ and successfully applied in at least one instance, ${ }^{53}$ but simulation studies have shown that the method has limited power to distinguish between a fully penetrant recessiverecessive model and single locus models with reduced penetrance. ${ }^{54}$ This is one avenue for future research in the genetics of $\mathrm{AD}$.

The results of our study shed light on the issue of heterogeneity. The notion that early onset $\mathrm{AD}$ is a distinct genetic entity is an attractive idea. Age at onset and genetic linkage studies support the existence of an autosomal dominant gene for very early onset familial $\mathrm{AD}$ (age of onset before 55 years). ${ }^{28-11}$ Clinically, however, the cut off age for early onset $\mathrm{AD}$ is considered to be 65 years. Our findings of the age of onset and segregation analysis suggest that autosomal dominant inheritance does not fit all cases with an onset of $\mathrm{AD}$ before the age of 65 . Furthermore, comparison of our findings with the results of a study of predominantly late onset $\mathrm{AD}^{29}$ suggests that at this level of analysis there is no apparent distinction in frequency of the autosomal dominant allele between cases of early onset and late onset AD. Similarity of the genetic models for early onset and late onset familial AD is consistent with the observed wide range in onset ages among affected relatives in both groups. It is possible that mechanisms determining susceptibility to AD may be the same for early and late onset illnesses, but that the age at onset may be influenced by other genetic or nongenetic factors as has been proposed in Huntington's disease. 5556

The evidence for a multifactorial effect is weak in our study of early onset $\mathrm{AD}$, but this needs to be confirmed in independent studies.
Given the low frequency of the AD susceptibility allele and the lack of strong environmental risk factors, the origin of familial aggregation of $\mathrm{AD}$ in some families remains an unresolved issue. Other complex forms of genetic susceptibility not accounted for by the present methodology may be implicated. The finding of reduced penetrance for the major dominant allele in the present study is indeed compatible with an oligogenic model.

Our findings are also of interest in light of the recent linkage studies of familial $\mathrm{AD}$. Familial early onset $\mathrm{AD}$ must be genetically heterogeneous, because the mutant gene in some families maps to chromosome $14^{8-11}$ whereas patients in other families have defects within the $\beta$ amyloid processing protein gene located on chromosome 21.3-7 Although the possibility of multiple loci has not been examined, our analysis and the segregation analysis by Farrer et $a l^{29}$ predict that it is unlikely that one dominant allele underlies the genetic basis in all cases. The hypothesis that non-mendelian inheritance may be involved in the genetic transmission of $\mathrm{AD}$ is supported by the finding of a strong association between Apo E4 and late onset AD. ${ }^{57}$

A challenge to genetic epidemiologists in the future may be to disentangle the various genetic and non-genetic factors implicated in AD. Oligogenic models and epistatic models are still to be explored. A profitable strategy in future research may be to incorporate existing clues about the multifactorial component, such as associations with the Apo E4, ${ }^{57}$ HLA-A2, ${ }^{58}$ age of the father at the time of birth,,$^{59}$ and other risk factors, ${ }^{60}$ in a regressive model analysis. ${ }^{61}$ In this way, it may be possible to distinguish meaningful subgroups which would be useful for a variety of clinical and research applications.

We thank Drs Wim Schulte, Teun Tanja, Rob Haaxma, Arie Lameris, and Rolf Saan for their contributions to this study. We are also grateful to Helen de Bruijn, Micheline de Haes, Jeanette Kamman, Hanneke van Meurs, and Caroline Valkenburg for help in data collection. Dan Kiely provided excellent technical assistance and Jemma Williams expertly prepared the manuscript. We thank Dr Richard $\mathrm{H}$ Myers for discussing the data with us. This work was supported by The Netherlands Organization for Scientific Research (NWO), the Eurodem EC Concerted Action on the Epidemiology of Dementia, PHS grant AG09029. LAF is a fellow of the Alfred P Sloan Foundation.

1 St George-Hyslop PH, Myers RH, Haines JL, et al. Familial Alzheimer's disease: progress and problems. Neurobiol ial Alzheimer's disease:

2 Farrer LA, Myers RH, Cupples LA, et al. Transmission and age at onset patterns in familial Alzheimer's disease: evidence for heterogeneity. Neurology 1990;40:395-403.

3 Goate A, Chartier-Harlin MC, Mullan M, et al. Segregation of a missense mutation in the amyloid precursor protein gene with familial Alzheimer's disease. Nature 1991;349:704-6.

4 Van Duijn CM, Hendriks L, Cruts $M$, et al. Amyloid precursor protein gene mutation in early-onset Alzheimer's disease. Lancet 1991;i:978.

5 Naruse S, Igarashi S, Kobayashi $\mathrm{H}$, et al. Missense mutation $\mathrm{Val} \rightarrow \mathrm{Ile}$ in exon 17 of amyloid precursor protein gene in Japanese familial Alzheimer's disease. Lancet 1991;i:978-9.

6 Murrell J, Farlow M, Ghetti B, Benson MD. A mutation in 
the amyloid precursor protein associated with hereditary Alzheimer disease. Science 1991;254:97-9.

7 Chartier-Harlin MC, Crawford F, Houlden H, et al. Earlyonset Alzheimer's disease caused by mutations at codon 717 of the $\beta$-amyloid precursor protein gene. Nature 1991;353:844-6.

8 Schellenberg GD, Bird TD, Wijsman EM, et al. Genetic linkage evidence for a familial Alzheimer's disease locus on chromosome 14. Science 1992;258:668-71.

9 St George-Hyslop PH, Haines JL, Rogaev E, et al. Genetic evidence for a novel familial Alzheimer disease locus on chromosome 14. Nature Genet 1992;2:330-4.

10 Van Broeckhoven C, Backhovens H, Cruts M, et al. Mapping of a gene predisposing to early-onset Alzheimer's ping of a gene predisposing to early-onset Alzheimer's
disease to chromosome 14q24.3. Nature Genet disease to $1992 ; 2: 335-9$.

11 Mullan $M$, Houlden $H$, Windelspecht $M$, et al. A locus for familial early-onset Alzheimer disease on the long arm of chromosome 14, proximal to the $\alpha 1$-antichymotrypsin gene. Nature Genet 1992;2:340-2.

12 Pericak-Vance MA, Bebout JL, Gaskell PC, et al. Linkage studies in familial Alzheimer disease: evidence for chromosome 19 linkage. Am $\mathcal{F}$ Hum Genet 1991;48:1034-50.

13 Heyman A, Wilkinson WE, Stafford JA, et al. Alzheimer' disease: a study of epidemiologic aspects. Ann Neurol 1984;15:335-41.

14 Amaducci LA, Fratiglioni L, Rocca WA, et al. A case study of an Italian population. Neurology 1986;36:922-31.

15 Fitch N, Becker R, Heller A. The inheritance of Alzheimer's disease: a new interpretation. Ann Neurol 1988;23:14-19.

16 Van Duijn CM, Clayton D, Chandra V, et al. Familial aggregation of Alzheimer's disease and related disorders: a collaborative re-analysis of case-con
Epidemiol 1991;20(suppl):S13-S21.

17 Kallman FJ. Genetic aspects of mental disorders in later life. In: Kaplan OJ, ed. Mental disorders in later life. 2n ed. Stanford: Stanford University Press, 1956: 26-46.

18 Jarvik LF, Ruth V, Matsuyama SS. Organic brain syndrome and aging: a six-year follow-up of surviving twins. Arch Gen Psychiatry 1980;37:280-6.

19 Nee LE, Eldridge R, Sunderland T, et al. Dementia of the Alzheimer type: clinical and family study of 22 twin pairs. Neurology 1987;37:359-63.

20 Rapoport SI, Pettigrew KD, Schapiro MB. Discordance and concordance of dementia of the Alzheimer type (DAT) in monozygotic twins indicate heritable and sporadic forms of Alzheimer's disease. Neurology sporadic forms

21 Haines JL. Invited editorial. The genetics of Alzheimer's disease. A teasing problem. Am $\mathcal{f}$ Hum Genet $1991 ; 48: 1021-5$

22 Sjogren T, Sjogren H, Lindgren GH. Morbus Alzheimer and Morbus Pick. A genetic, clinical, and patho-anatomical study. Acta Psychiatr Neurol Scand 1952;82(suppl): 1-152.

23 Heston LL, Mastri AR. The genetics of Alzheimer's disease: associations with hematologic malignancy and Down syndrome. Arch Gen Psychiatry 1977;34:976-81.

24 Breitner JCS, Silverman JS, Mohs RC, Davis KL. Familial aggregation in Alzheimer's disease: comparison of risk among relatives of early and late-onset cases and among male and female relatives in successive generations. Neurology 1988;38:207-12.

25 Huff FJ, Auerbach J, Chakravarti A, Boller F. Risk of dementia in relatives of patients with Alzheimer disease. dementia in relatives of patie

26 Martin RL, Gerteis G, Gabrielli WF Jr. A family-genetic study of dementia of Alzheimer type. Arch Gen Psychiatry 1988;45:894-900.

27 Farrer LA, O'Sullivan DM, Cupples LA, et al. Assessment of genetic risk for Alzheimer's disease among first-degree relatives. Ann Neurol 1989;25:485-93.

28 Heston LL. Genetic studies of dementia: with emphasis on Parkinson's disease and Alzheimer's neuropathology. In Mortimer JA, Schuman LM, eds. The epidemiology of dementia. New York: Oxford University Press, 1981.

29 Farrer LA, Myers RH, Connor L, et al. Segregation analysis reveals evidence of a major gene for Alzheimer disease. Am f Hum Genet 1991;48:1026-33.

30 Hofman A, Schulte W, Tanja TA, et al. History of dementia and Parkinson's disease in $1 \mathrm{st}$-degree relatives of patients with Alzheimer's disease. Neurology 1989;39:1589-92.

31 McKhann G, Drachman D, Folstein M, et al. Clinical diagnosis of Alzheimer's disease: report of the NINCDS ADRDA Work Group. Neurology 1984;34:939-44

32 Hughes CP, Berg L, Danziger WL, et al. A new clinical scale for the staging of dementia. $\mathrm{Br} \mathcal{F}$ Psychiatry 1982;140:566-72.

33 Pfeiffer E. A short portable mental status questionnaire for the assessment of organic brain deficit in elderly patients. f Am Geriatr Soc 1975;23:433-41.

34 Hachinski VC, Iiff LD, Zihka E, et al. Cerebral blood flow in dementia. Arch Neurol 1975;32:632-7.

35 Cupples LA, Risch N, Farrer LA, Myers RH. Estimation of age at onset with missing information on onset. Am $\mathcal{f ~ H u m}$ Genet 1991;49:76-87.

36 Cupples LA, Terrin NC, Myers RH, D'Agostino RB. Using survival methods to estimate age at onset distributions for genetic diseases with an application to Huntington disease. Genet Epidemiol 1989;6:361-71.

37 Sokal RR, Rohlf FJ. Biometry. San Francisco: WH Freeman and Company, 1969.

38 Morton NE. Genetic tests under incomplete ascertainment. Am $\mathcal{F}$ Hum Genet 1959;11:1-16.

39 Morton NE, MacLean CJ. Analysis of family resemblance. III. Complex segregation of quantitative traits. $\mathrm{Am} \dot{f}$ Hum Genet 1974;26:489-503.

40 Lalouel JM, Rao DC, Morton NE, Elston RC. A unified model for complex segregation analysis. Am $\mathcal{F}$ Hum Genet 1983;35:816-26.

41 Lalouel JM, Morton NE. Complex segregation analysis with pointers. Hum Hered 1981;31:312-21.

42 Emery AEH. Methodology in medical genetics. An introduction to statistical methods. 2nd ed. New York: Churchill Livingston, 1986.

43 Mayeux R, Sano M, Chen J, et al. Risk of dementia in firstdegree relatives of patients with Alzheimer's disease and related disorders. Arch Neurol 1991;48:269-73.

44 McGuffin P, Sargeant M, Weppner G. The genetics of Alzheimer's disease and the ethical implications for prevention. In: Sram R, Bulyzhenkov V, Prilipko L, Christen Y, eds. Ethical issues of molecular genetics in psychiatry. New York: Springer-Verlag, 1991: 42-56.

45 Larsson T, Sjogren T, Jacobson G. Senile dementia: a clinical, sociomedical and genetic study. Acta Psychiatr Scand 1963;39(suppl):1-259.

46 Schoenberg BS, Kokmen E, Okazaki H. Alzheimer's disease and other dementing illnesses in a defined United States population: incidence rates and clinical features. Ann Neurol 1987;22:724-9.

47 Breitner JCS, Magruder-Habib KM. Criteria for onset critically influence the estimation of familial risk in Alzheimer's disease. Genet Epidemiol 1989;6:663-9.

48 Silverman JM, Breitner JC, Mohs RC, David KC. Reliability of the family history method in genetic studies of Alzheimer's disease and related dementias. Am $\mathcal{f}$ Psychiatry 1986;143:1279-82.

49 Hasstedt SJ, Cartwright PE. PAP: pedigree analysis package, revision 2, Technical Report No 13. Department of Biophysics and Computing, University of Utah Medical Center, 1981.

50 Bailey-Wilson JE, Elston RC. Statistical analysis for genetic epidemiology $(S A G E)$. LSU Medical Center, New epidemiology (SAGE).

51 Lange K, Boehnke M. Extensions to pedigree analysis. V. Optimal calculation of Mendelian likelihoods. Hum Hered 1983;33:291-301

52 Elandt-Johnson RC. Segregation analysis for complex modes of inheritance. Am $\mathcal{J}$ Med Genet 1970;22:129-94.

3 Greenberg DA, Lange KL. A maximum likelihood test of the two-locus model for coeliac disease. Am $\mathcal{Y}$ Med Genet 1982;12:75-82.

54 Greenberg DA. Simulation studies of segregation analysis: application of two-locus models. Am $\mathcal{f}$ Hum Genet 1984;36:167-76.

55 Farrer LA, Conneally PM. A genetic model for age at onset in LA, Conneally PM. A genetic model for age at onset

56 Ridley RM, Frith CD, Crow TJ, Conneally PM. Anticipation in Huntington's disease is inherited through the male tion in Huntington's disease is inherited through the male
line but may originate in the female. $f$ Med Genet line but may orig.

57 Saunders AM, Strittmatter WJ, Schmechel D, et al. Association of apolipoprotein $\varepsilon E$ allele 4 with late-onset familial and sporadic Alzheimer's disease. Neurology (in press).

58 Payami H, Kaye J, Becker W, et al. HLA-A2, or a closely linked gene, confers susceptibility to early-onset sporadic Alzheimer's disease in men. Neurology 1991;41:1544-8.

59 Farrer LA, Cupples LA, Connor L, et al. Association of decreased paternal age and late-onset Alzheimer disease: an example of genetic imprinting? Arch Neurol an example of

60 Van Duijn CM, Hofman A, for the EURODEM risk factors research group. Risk factors for Alzheimer's disease: the
EURODEM re-analysis of case-control studies. NeuroEURODEM re-analysis of case-contro

61 Bonney GE. On the statistical determination of major gene mechanisms in continuous human traits: regressive models. Am $\mathcal{F}$ Med Genet 1984;18:731-49. 